\title{
$\mathrm{Fe}_{2} \mathrm{VAl}$ の電子構造と熱電物性における 重元素部分置換効果
}

\author{
寺澤佑 -1 ,* 三上祐史 ${ }^{2}$ 伊藤孝至 ${ }^{3}$ \\ 1名古屋大学大学院工学研究科マテリアル理工学専攻応用物理学分野
2独立行政法人産業技術総合研究所サステナブルマテリアル研究部門
3名古屋大学エコトピア研究所
}

竹内 恒 博 1,3

J. Japan Inst. Metals, Vol. 76, No. 3 (2012), pp. 216-221

(C) 2012 The Japan Institute of Metals

\section{Effects of Heavy Element Substitution on Electronic Structure and Lattice Thermal Conductivity of $\mathrm{Fe}_{2} \mathrm{VAl}$ Thermoelectric Material}

\author{
Yuichi Terazawa ${ }^{1, *}$, Masashi Mikami², Takashi Itoh ${ }^{3}$ and Tsunehiro Takeuchi ${ }^{1,3}$ \\ ${ }^{1}$ Department of Applied Physics, Graduate School of Engineering, Nagoya University, Nagoya 464-8603 \\ ${ }^{2}$ Materials Research Institute for Sustainable Development, National Institute of Advanced Industrial Science and Technology, \\ Nagoya 463-8560 \\ ${ }^{3}$ EcoTopia Science Institute, Nagoya University, Nagoya 464-8603
}

By using first principles cluster calculations, we identified that Ta or $\mathrm{W}$ substitution for $\mathrm{V}$ is useful for decreasing the lattice thermal conductivity of the $\mathrm{Fe}_{2} \mathrm{VAl}$ Heusler alloy without greatly affecting the electron transport properties. It was clearly confirmed that the $\mathrm{Fe}_{2}\left(\mathrm{~V}_{1-x} \mathrm{Ta}_{x}\right) \mathrm{Al}_{0.95} \mathrm{Si}_{0.05}(x=0,0.025,0.05), \mathrm{Fe}_{2}\left(\mathrm{~V}_{0.9-x} \mathrm{Ta}_{x} \mathrm{Ti}_{0.1}\right) \mathrm{Al}(x=0,0.10,0.20)$, and $\mathrm{Fe}_{2}\left(\mathrm{~V}_{0.9-2 x} \mathrm{~W}_{x} \mathrm{Ti}_{0.1+x}\right) \mathrm{Al}$ $(x=0,0.05,0.10)$ alloys indeed possessed large Seebeck coefficient regardless of the amounts of substituted elements, while their lattice thermal conductivity was effectively reduced. As a result of partial substitution of Ta for $\mathrm{V}$, we succeeded in increasing the magnitude of the dimensionless figure of merit of the Heusler phase up to 0.18, which is five times as large as the Ta-free compound.

(Received October 26, 2011; Accepted December 28, 2011; Published March 1, 2012)

Keywords: thermoelectric properties, electronic structure, band calculation, cluster calculation, Heusler alloy

\section{1. 緒言}

石油に代表される化石燃料を燃焼させることで得られるエ ネルギーの大部分は $500 \mathrm{~K}$ 以下の低温廃熱として捨てられ ている．熱電発電を利用することで廃熱から効率的に電気を 生久出すためには, $500 \mathrm{~K}$ 以下の低温に拈いてよい性能を示 す熱電素子を利用することが望ましい。 また，拡散的に広が る廃熱の回収には多くの素子が必要であることを考慮する と, できるだけ安価であり, 廃棄後に環境に負荷を与えない ことが必要であると考えられる。しかし, この温度領域で利 用可能な熱電材料は, タリウム, 鉛, ビスマス, テルルなど の危険な有毒元素や高価な希少元素を含んでおり，この特徵 が, 熱電発電の普及を著しく阻害している. 安価で環境に優 しい元素のみから構成され, 室温から $500 \mathrm{~K}$ 程度の温度領 域で大きな $Z T$ を示す新たな熱電材料の開発が強く望まれる.

ホイスラー型 $\mathrm{Fe}_{2} \mathrm{VAl}$ は安価で無害な元素のみから構成さ れ，大きなゼーベック係数と金属的な電気伝導を示すことか

\footnotetext{
* 名古屋大学大学院生 (Graduate Student, Nagoya University)
}

ら，環境調和型熱電材料として期待されている1-3)。しか し, 格子熱伝導度が大きいために, 現状では大きな無次元性 能指数 $Z T$ が得られていない. $\mathrm{Fe}_{2} \mathrm{VAl}$ を熱電材料として実 用化するためには, 電子物性の特徵を維持したまま, 格子熱 伝導度だけを低減させることが必要である.

格子熱伝導度を低減させるには, 重元素による構成元素の 部分置換が有効である ${ }^{4)}$. 構成元素を重元素で部分置換する ことで, (a)フォノンの群速度を低減させ ${ }^{5)}$, (b)フォノンの ウムクラップ散乱を増加させ ${ }^{5)},(\mathrm{c})$ 不規則性によるフォノ ンの散乱確率を増大させることができるからである3,6). 不 規則性を導入すると, 一般的に, 電気伝導度は低下し, $Z T$ を小さくしてしまう.しかしながら, 大変都合のよいこと に, 電気伝導度の温度依存性が弱いことから, $\mathrm{Fe}_{2} \mathrm{VAl}$ 系合 金では, 熱電材料としての実用温度領域に掞いて, IoffeRegel 極限 (平均自由行程が原子間距離程度になで短くなっ ている極限)7)が実現していると判断される.この状況で は, 不規則性を与えても電子の平均自由行程に大きな変化が 生じないはずである.すなわち, $\mathrm{Fe}_{2} \mathrm{VAl}$ 系合金の構成元素 を重元素で部分置換したとしても, フェルミ準位近傍に不純 物準位が形成されなければ, 電気伝導度やゼーベック係数に 
はほとんど変化は表れず，電子物性の特徵を保ったまま，格 子熱伝導度のみを低減できるはずである.

そこで本研究では, 置換元素によるフェルミ準位近傍の電 子構造の変化を, 第一原理計算を用いて詳細に調べること で, 電子輸送特性に大きな影響を与えることなく格子熱伝導 度のみを効果的に低減させることができる可能性が高い元素 を特定することを第一の目的とした. さらに，特定した置換 元素を用いて $\mathrm{Fe}_{2} \mathrm{VAl}$ 系熱電材料の性能を向上させることを 第二の目的とした.

\section{2. 計算手順と実験手順}

$\mathrm{Fe}_{2} \mathrm{VAl}$ ホイスラー相はフェルミ準位近傍に擬ギャップを 有していることが知られている. また，この擬ギャップの存 在により，良好な熱電物性が得られていると考えられてい る.この電子構造の特徵は, 主に, $\mathrm{Fe} 3 d$ 軌道と V $3 d$ 軌道を 主成分とするバンドによって作り出されている， $d$ 軌道を主 成分とするバンドのエネルギーは, 概ね, 遷移金属元素周り の原子配置によって決定されているため, 比較的小さなクラ スターを用いたクラスター計算でも，元素置換が擬ギャップ に与える影響を予測可能であると判断される. また, 不純物 元素周りに形成される局所的な波動関数のエネルギー固有值 は，周期性を前提としたバンド計算で予測することは難しい が，クラスター計算であれば予測できるはずである，上記の 考察に基づき, 本研究では, バンド計算だけでなくクラス ター計算を主要な計算手法として採用した ${ }^{4)}$.

本研究では Discrete Variational X $\alpha$ Potential Method $(\mathrm{DVX} \alpha)$ と呼ばれるクラスター計算プログラムを用い た ${ }^{4,8)}$. このプログラムでは, 電子相関を表すポテンシャル としてX $\alpha$ ポテンシャルを用い, 波動関数として原子軌道法 の線形結合から得られる波動関数 (Linear Combination of Atomic Orbital Method)を用いている.さらに，バンド計算 を Full-potential Linearized Augmented Plane-wave (FLAPW) 法を用いた WIEN2k と, 擬ポテンシャル法を用 いたPHASEを利用して行った。いずれの計算プログラム に掞いても, Local Density Approximation (LDA)や Generalized Gradient Approximation (GGA)を用いて密度汎関数 法に基づいた電子状態の計算が可能である. なお, 本研究で 実施した計算には後者(GGA)を用いた.

用いている基底関数やポテンシャルの違いにより, 計算に 要する時間や, 得られる結果にも違いが生じることに注意し ておく必要がある。FLAPW 法は実験結果をよく再現する が，基底関数の数が多いために，計算量を必要とする。一 方, 擬ポテンシャル法では基底関数を少なくすることで計算 量を少なくすることが可能である. 本研究では, 部分置換を 施していない $\mathrm{Fe}_{2} \mathrm{VAl}$ の電子構造の計算には精度の高い計算 結果が得られる FLAPW 法(WIEN2k) ${ }^{9,10)}$ を利用した。 た, 不純物元素を導入した際の電子構造は, 比較的短時間に 計算結果が得られ，構造最適化が容易である擬ポテンシャル 法 $(\mathrm{PHASE})^{11)}$ とクラスター計算 $(\mathrm{DVX} \alpha)$ を利用した。

以下に $\mathrm{Fe}_{2} \mathrm{VAl}$ 系合金中に抢ける置換元素のエネルギー準 位を求める手法を示す. 初めに, 擬ポテンシャル法を用いた (a)

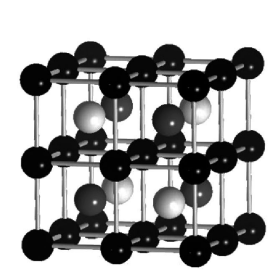

(b)

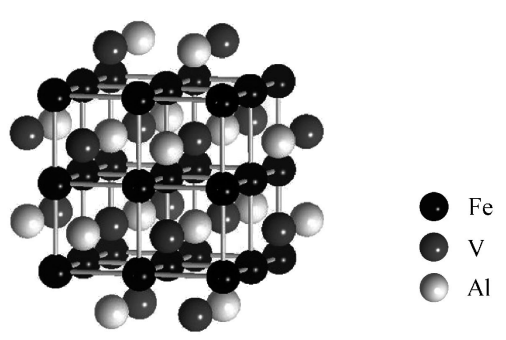

Fig. 1 Schematic illustrations of (a) the unit cell of $\mathrm{Fe}_{2} \mathrm{VAl}$, and (b) 59-atom cluster employed for the present cluster calculations.

バンド計算 $(\mathrm{PHASE})$ を用いて, $\mathrm{Fe}_{2} \mathrm{VAl}$ 単位胞のうち一つ の原子を不純物原子で置換した際の構造の最適化を行った. 次に，不純物原子を中心とした 59 原子のクラスター(Fig. 1 を参照)を最適化した結晶構造から抜き出し, DVX $\alpha$ 法を用 いてクラスター準位を計算した. 固体中に存在する遷移金属 元素の $d$ 軌道は配位原子の軌道との重なり積分が小さいた めに, 表面の影響を受けにくいクラスター中心に存在する遷 移元素の $d$ 成分を主成分とするクラスター準位は, 結晶に 打ける $d$ 軌道を主成分とするバンドのエネルギーに概ね一 致するはずである，一方，クラスター表面に位置する原子の 軌道を主成分とするクラスター準位は, 固体内の電子状態を 反映しないと考えられる.この考察に基づき, 中心に置換元 素(遷移金属元素)を配置した比較的大きなクラスターのクラ スター準位を計算し，中心元素の $d$ 成分のみを抜き出すこ とで, 不純物元素が作り出す部分状態密度を求めた。

電子構造から特定した重元素の有効性を確認するために, 理論計算により導出した組成の試料を作製した。純度 99.9 〜 99.99\%の原料を Ar 雾囲気でアーク溶解することで母合 金を作製した。 また，得られた母合金を真空において 1273 $\mathrm{K}$ で 48 時間の熱処理を施すことで物性測定用試料とした。 試料内に含有される結晶相は, $\mathrm{Cu}-\mathrm{K} \alpha$ 線を線源とした粉末 X 線回折測定 (RIGAKU RINT 2000) により同定した.

作製した試料に対して電気抵抗率, ゼーベック係数, 熱伝 導度の測定を行った．電気抵抗率は四端子法を用いて $10 〜$ $400 \mathrm{~K}$ の温度域で, ゼーベック係数は定常法を用いて 200〜 $400 \mathrm{~K}$ の温度域で, 熱伝導度は緩和法を用いて $300 \mathrm{~K}$ で測 定した.

\section{3. 結果}

\section{1 電子構造計算}

Fig. 2 に DVX $\alpha$ 法を用いて計算した $\mathrm{Fe}_{2} \mathrm{VAl}$ の $\mathrm{Fe} 3 d$ と $\mathrm{V} 3 d$ の部分状態密度と WIEN2k (FLAPW-GGA 法)を用い て計算した状態密度を示す. DVX $\alpha$ 法により計算された部 分状態密度が FLAPW-GGA 法で計算された状態密度の特 徵をよく再現していることを確認できる。この結果から， $\mathrm{Fe}_{2} \mathrm{VAl}$ の擬ギャップの形状に直接関わってくる $d$ 軌道の情 報は, ごく簡単なクラスター計算を用いて概ね正確に評価で きると言える. 
(a)

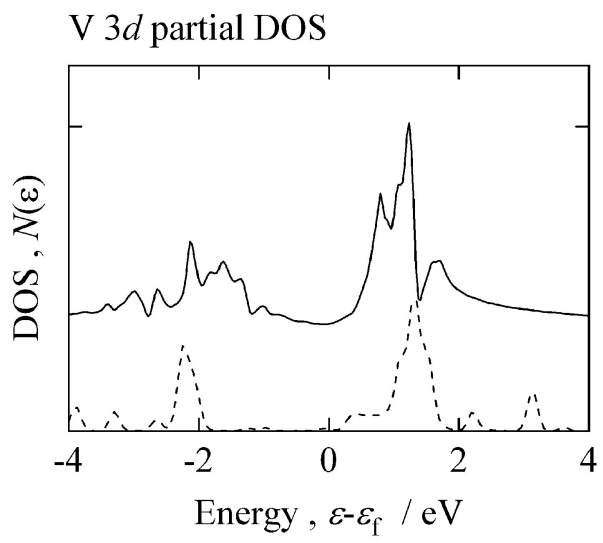

(b)

Fe $3 d$ partial DOS

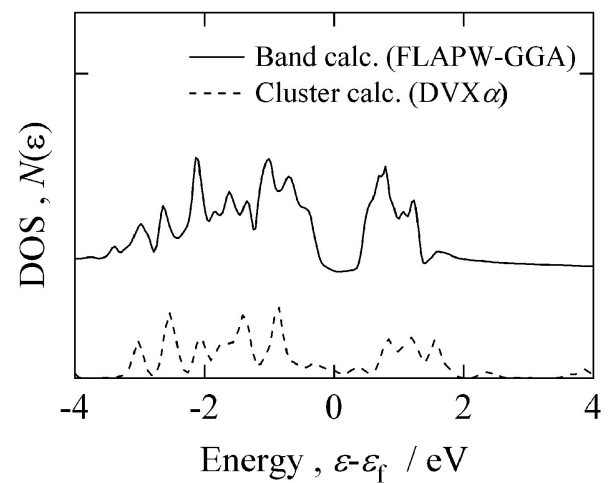

Fig. 2 (a) V $3 d$ partial density of states and (b) $\mathrm{Fe} 3 d$ partial density of states calculated for the $\mathrm{Fe}_{2} \mathrm{VAl}$ alloy. Solid lines indicate the partial density of states obtained by the FLAPW-GGA band calculations, while the dashed lines show those from the DVX $\alpha$ cluster calculation. The two different calculations provide us with very similar characteristics in the partial density of states, which encouraged us to employ the cluster calculations to investigate the electronic structure of substituted elements.

$\mathrm{Fe}_{2} \mathrm{VAl}$ で観測される大きなゼーベック係数は擬ギャップ に起因している．部分的な元素置換により生み出される不純 物準位が擬ギャップ内に存在すると，置換によりゼーベック 係数は小さくなると予想される，したがって，たとえ格子熱 伝導度が効果的に減少しても, 実用的な熱電材料にはなり得 ないであろう． $\mathrm{Fe}_{2} \mathrm{VAl}$ に対するバンド計算では，擬ギャッ プが $-0.2<\varepsilon-\varepsilon_{\mathrm{f}}<0.3 \mathrm{eV}$ に位置していることから，このエ ネルギー領域にクラスター準位を形成しない置換元素を見出 す必要があると言える。な拝，一般的に，化合物に打ける各 々の原子サイトに電子濃度が大きく異なる元素が置換する可 能性は低いと考えられる。したがって, $\mathrm{Fe}_{2} \mathrm{VAl}$ に適用可能 な置換元素として, $\mathrm{V}$ や $\mathrm{Fe}$ の同族元素, あるいはその両隣 のコラムの元素を置換元素として選択するべきであると考え た．この考察に基づき， $\mathrm{V}$ サイトの置換元素として $\mathrm{Zr}, \mathrm{Nb}$, $\mathrm{Mo}, \mathrm{Hf}, \mathrm{Ta}, \mathrm{W}$ を, Fe サイトの置換元素として Tc, Ru, Rh, Re, Os, Ir を選択した.

Fig. 3 に 59 原子クラスターを用いたクラスター計算から 得られた部分状態密度 $(d$ 成分)を示す。計算により得られた 部分状態密度から，(a) V サイトへの $\mathrm{Zr}, \mathrm{Nb}, \mathrm{Hf}$, Ta 置換, 抢よび，(b) Fe サイトへの Ru, Rh, Ir 置換が $p$ 型抢よび $n$ 型材料の双方に対して有効であることが分かった．また， (c) $\mathrm{V}$ サイトへの Mo, $\mathrm{W}$ 置換は $p$ 型材料に限り有効である と判断した.これらの元素が作り出す不純物準位は擬ギャッ プの形状に大きな影響を与えないことから，置換元素として 用いた場合に電子輸送特性には大きな影響を与えないと考え られる. 一方，ここで選択した置換元素はすべて $\mathrm{Fe}, \mathrm{V}$ に 比べてはるかに重い元素であるため, フォハン分散の変調と 不純物フォノン散乱の増大を通して格子熱伝導度は著しく低 減させることができると予想される。

より効果的に格子熱伝導度を低減させるためには, より重 たい元素で置換することが有効である2).すなわち， $4 d$ 元素 $(\mathrm{Zr}, \mathrm{Nb}, \mathrm{Mo}, \mathrm{Ru}, \mathrm{Rh})$ で置換するよりも, $5 d$ 元素 (Ir, Hf, Ta, W)で置換することが望ましい，ただし，Ir, Hf は非常に高 価な元素であるため, 本研究では $\mathrm{V}$ サイトを $\mathrm{Ta}$ あるいは
$\mathrm{W}$ で部分置換することがよいと判断した.

\section{2 電子輸送特性と熱伝導度}

前節では, 第一原理計算を駆使して, $\mathrm{Fe}_{2} \mathrm{VAl}$ の構成元素 を部分置換することで, 電子輸送特性には大きな影響を与え ずに格子熱伝導度を低減できる可能性の高い重元素 $(\mathrm{Ta}, \mathrm{W})$ を特定した。本節では, この理論的予測が正しいことを実験 により検証した結果を記す。

構成元素の部分置換により電子濃度に変化が生じる場合が ある. 電子濃度の变化による物性变化と電子構造の変化によ る物性変化を分離するためには, 電子濃度の変化を防ぐ必要 がある. 本研究では, 電子数を増やす場合には $\mathrm{Al}$ サイトを $\mathrm{Si}$ で, 電子数を減らす場合には $\mathrm{V}$ サイトを $\mathrm{Ti}$ で部分置換す ることで, 重元素置換による電子濃度変化を補正し, 試料の 電子濃度を一定に保った. $\mathrm{Al}$ と $\mathrm{Si}$ は $s, p$ 電子のみを系に提 供することから, $\mathrm{Al}$ を $\mathrm{Si}$ で部分置換した場合, バンド構造 を大きく変えることなく電子数を増やすことができると判断 した．一方，Vサイトに Ti を置換した場合には， $d$ バンド の変化による擬ギャップへの影響があると考える読者もいる かもしれない．しかし， $\mathrm{Fe}_{2} \mathrm{VAl} の \mathrm{~V}$ サイトに Ti が存在す る場合の不純物準位をクラスター計算により調べたところ,

Fig. 4 に示すと抢り, V サイトの Ti による部分置換は擬ギ ヤップの構造に影響を与えないことが判明した。この結果を 考虑して, 電子濃度補正方法の一つとしてVサイトの Tiに よる部分置換を採用した。

以上に示した指針から，(1) $\mathrm{Fe}_{2}\left(\mathrm{~V}_{1-x} \mathrm{Ta}_{x}\right) \mathrm{Al}_{0.95} \mathrm{Si}_{0.05} \quad(x=0$, $0.025,0.05)$, (2) $\mathrm{Fe}_{2}\left(\mathrm{~V}_{0.9-x} \mathrm{Ta}_{x} \mathrm{Ti}_{0.1}\right) \mathrm{Al}(x=0,0.10,0.20)$, (3) $\mathrm{Fe}_{2}\left(\mathrm{~V}_{0.9-2 x} \mathrm{~W}_{x} \mathrm{Ti}_{0.1+x}\right) \mathrm{Al}(x=0,0.05,0.10)$ の 3 種類の試料を 作製し, 電気抵抗率, ゼーベック倸数, 熱伝導度を測定した。

Fig. 5 に, (a) $\mathrm{Fe}_{2}\left(\mathrm{~V}_{1-x} \mathrm{Ta}_{x}\right) \mathrm{Al}_{0.95} \mathrm{Si}_{0.05}(x=0,0.025$, $0.05)$, (b) $\mathrm{Fe}_{2}\left(\mathrm{~V}_{0.9-x} \mathrm{Ta}_{x} \mathrm{Ti}_{0.1}\right) \mathrm{Al}(x=0,0.10,0.20)$, (c) $\mathrm{Fe}_{2}\left(\mathrm{~V}_{0.9-2 x} \mathrm{~W}_{x} \mathrm{Ti}_{0.1+x}\right) \mathrm{Al}(x=0,0.05,0.10)$ の順に室温での 熱伝導度を重元素置換量 $x$ の関数として示す. $x$ の増大に伴 い，熱伝導度が著しく減少していることが分かる.ビーデマ 
(a) V site substitution
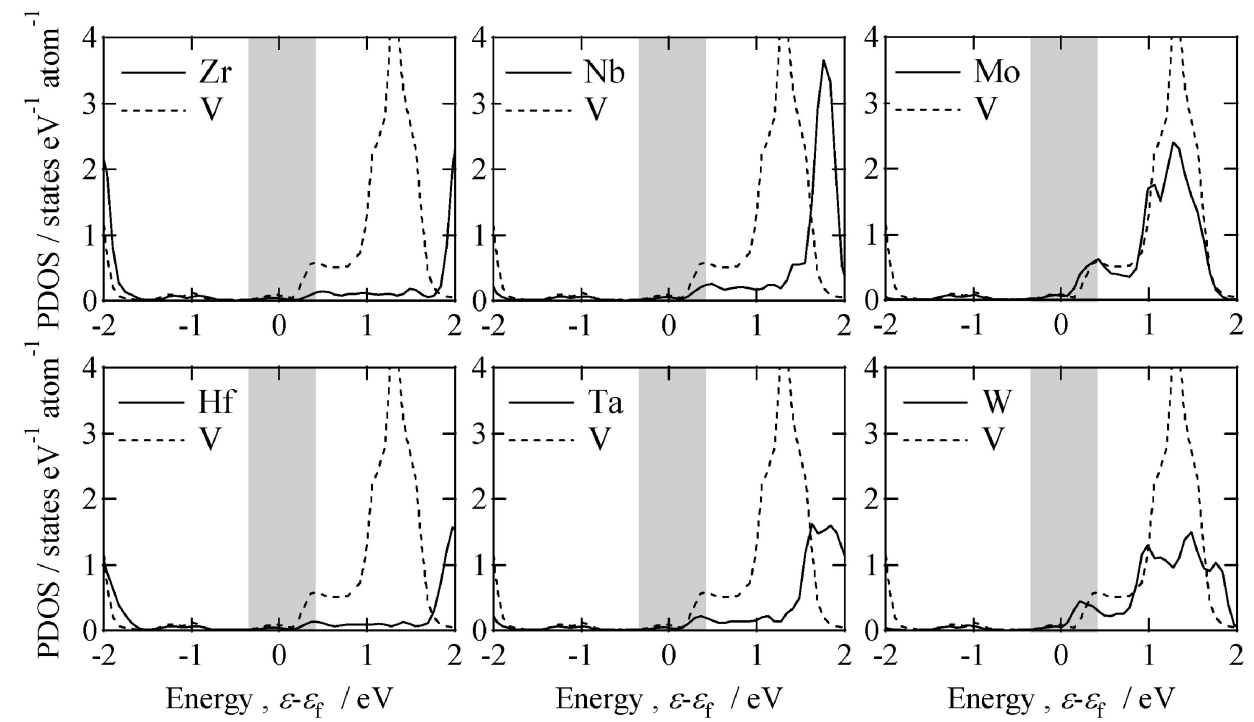

(b) Fe site substitution
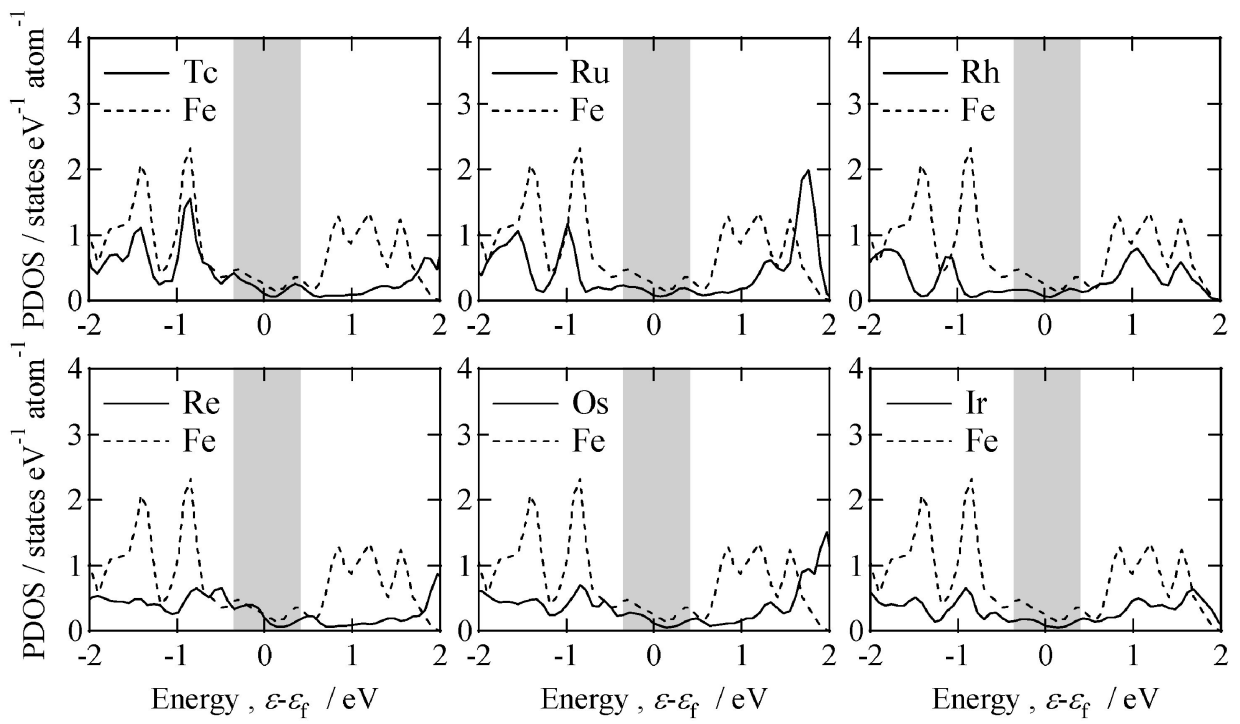

Fig. 3 Partial density of states of the $d$-component of a transition-metal element substituted for $\mathrm{V}$ or $\mathrm{Fe}$ in the coordination cluster of $\mathrm{Fe}_{2} \mathrm{VAl}$. The gray area indicates the energy range of the pseudpgap. Absence of any cluster levels in this energy range is required to retain the good thermoelectric properties of $\mathrm{Fe}_{2} \mathrm{VAl}$.

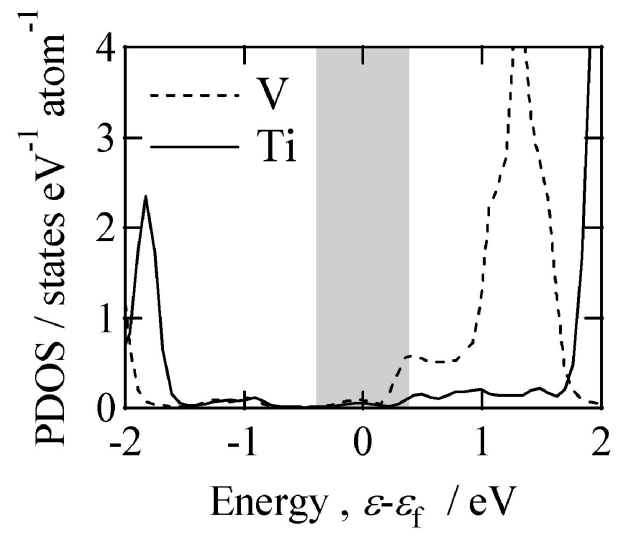

Fig. 4 Partial density of states of the $d$-component of Ti substituted for $\mathrm{V}$ in the coordination cluster of $\mathrm{Fe}_{2} \mathrm{VAl}$.
ン・フランッ則を用いて電子の寄与による熱伝導度を大雑把 に見積もると, 熱伝導度の減少は主に格子熱伝導度の減少に よって引き起こされていることが分かる.

Fig. 6 亿電気抵抗率, ゼーベック係数, 出力因子を示す. 第一原理クラスター計算から予測したとおり, Ta, W で部 分置換しても電子輸送特性には大きな影響がなく, 出力因子 が維持されていることが分かる．この結果から, 第一原理計 算を利用することで, 熱電材料の電子輸送特性にはほとんど 影響を与えずに, 格子熱伝導度の反を低減させることに成功 したといえる。

Ta 置換を行った $n$ 型試料 $\mathrm{Fe}_{2}\left(\mathrm{~V}_{1-x} \mathrm{Ta}_{x}\right) \mathrm{Al}_{0.95} \mathrm{Si}_{0.05}(x=0$, $0.025,0.05)$ のゼーベック係数は, Taの置換量に伴い, わず かではあるが増大している，この増大は，第一原理計算から は単純には予測できなかった．このゼーベック係数の増大の 

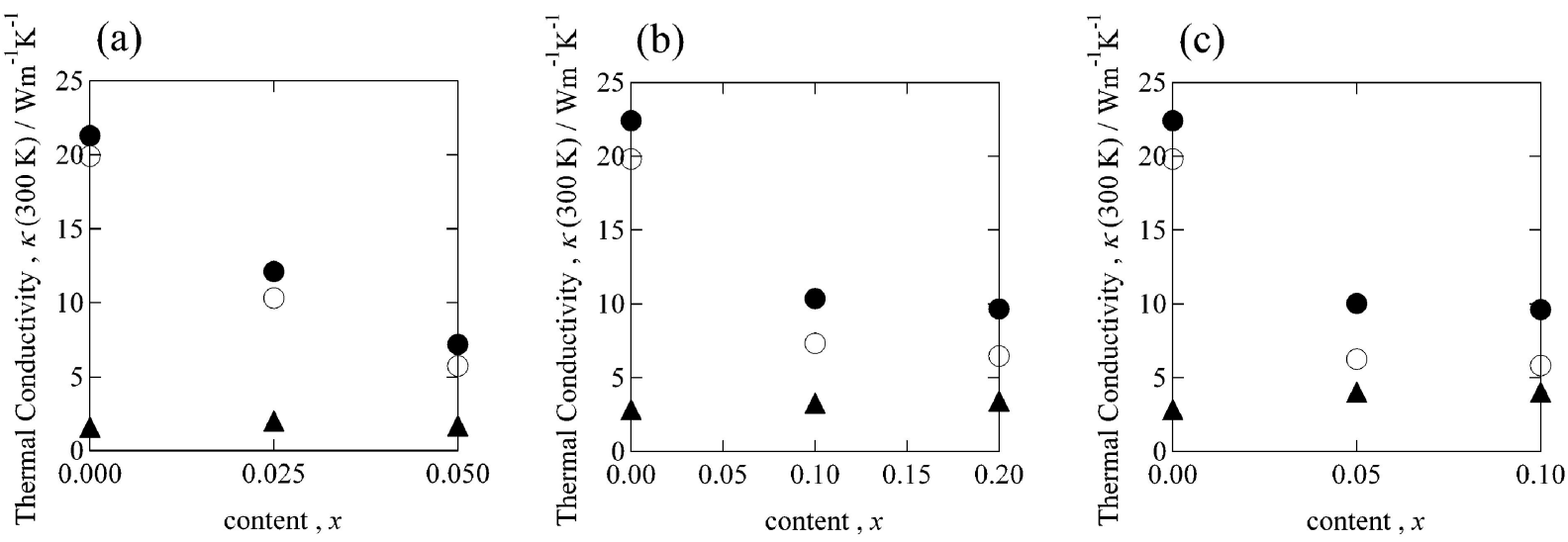

Fig. 5 Thermal conductivity (solid circles) measured for (a) $\mathrm{Fe}_{2}\left(\mathrm{~V}_{1}, \mathrm{Ta}_{x}\right) \mathrm{Al}_{0.95} \mathrm{Si}_{0.05}(x=0,0.025,0.05)$, (b) $\mathrm{Fe}_{2}\left(\mathrm{~V}_{0.9-x} \mathrm{Ta}_{2} \mathrm{Ti}_{0.1}\right) \mathrm{Al}$ $(x=0,0.10,0.20)$, and (c) $\mathrm{Fe}_{2}\left(\mathrm{~V}_{0.9-2 x} \mathrm{~W}_{x} \mathrm{Ti}_{0.1+x}\right) \mathrm{Al}(x=0,0.05,0.10)$ at room temperature. Electron thermal conductivity, $\kappa_{\mathrm{WFL}}$ (solid triangles), and lattice thermal conductivity, $\kappa-\kappa_{\mathrm{WFL}}$ (open circles), were roughly estimated by using the Wiedemann-Franz law.
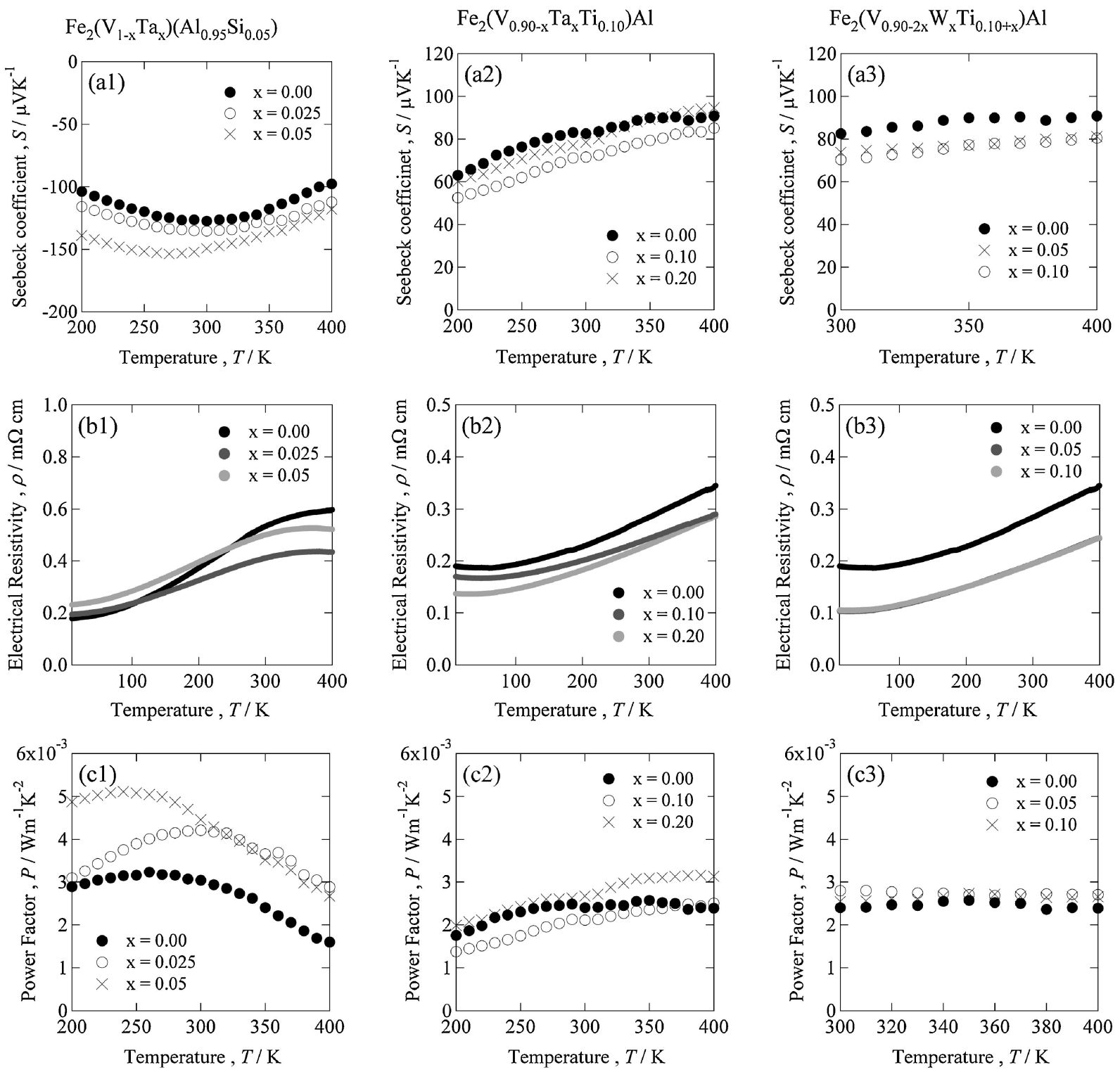

Fig. 6 Temperature dependence of (a) Seebeck coefficient, (b) electrical resistivity, and (c) power factor of $\mathrm{Fe}_{2}\left(\mathrm{~V}_{1-x} \mathrm{Ta}_{x}\right) \mathrm{Al}_{0.95} \mathrm{Si}_{0.05}(x=0,0.025,0.05), \mathrm{Fe}_{2}\left(\mathrm{~V}_{0.9-x} \mathrm{Ta}_{x} \mathrm{Ti}_{0.1}\right) \mathrm{Al}(x=0,0.10,0.20)$ and $\mathrm{Fe}_{2}\left(\mathrm{~V}_{0.9-2 x} \mathrm{~W}_{x} \mathrm{Ti}_{0.1+x}\right) \mathrm{Al}$ $(x=0,0.05,0.10)$. 
効果により, 出力因子は $5 \times 10^{-3}$ にまで到達し, 格子熱伝 導度の大幅な減少との相乗効果によって, $300 \mathrm{~K}$ に打ける $Z T$ が 0.18 まで向上した。この值は $5 d$ 重元素を含まない $\mathrm{Fe}_{2} \mathrm{VAl}_{0.95} \mathrm{Si}_{0.05}$ の約 5 倍に相当する.

\section{4. 考察}

我々は, ごく単純な考察から, 格子熱伝導度が電子熱伝導 度に匹敵するほど小さい場合において熱電変換材料が $Z T>$ 1 を示すためには, ゼーベック係数が $200 \mu \mathrm{V} / \mathrm{K}$ を超える大 きさが必要であることを報告してきた ${ }^{12)}$. 残念ながら，本 研究で用いた $\mathrm{Fe}_{2} \mathrm{VAl}$ 系熱電材料は, 格子熱伝導度は未だに 電子熱伝導度よりも大きく, ゼーベック係数も $200 \mu \mathrm{V} / \mathrm{K}$ をはるかに下回っている． $\mathrm{Fe}_{2} \mathrm{VAl}$ を実用的な熱電材料とし て利用するためには，格子熱伝導度をさらに低減させるだけ ではなく, ゼーベック係数の絶対值を大幅に増大させなくて はならない。

本研究において, V サイトに Taを部分置換することで, ゼーベック係数の絶対值が約 $160 \mu \mathrm{V} / \mathrm{K}$ まで増大した．こ のゼーベック係数の大きさで $Z T \sim 1$ を実現するためには， 格子熱伝導度が電子熱伝導度に比べて無視できるほど小さく なくてはならない，本研究において重元素置換により得られ た比較的小さな格子熱伝導度をさらに低減させるためには, 重元素部分置換と他の効果的な手法を併用する必要があると 判断する.

超格子構造を利用することで格子熱伝導度が著しく低減す ることが, 理論的にも, 実験的にも確かめられている13,14). この手法を用いることで，極めて小さな格子熱伝導度と大き な無次元性能指数 $Z T$ を有する $\mathrm{Fe}_{2} \mathrm{VAl}$ 系熱電材料が開発で きると予測される. 我々は, 現在, $\mathrm{Fe}_{2} \mathrm{VAl}$ 系熱電材料の超 格子薄膜の作製を試みている. 超格子構造による格子熱伝導 度低減効果は，別の機会に報告する予定である.

\section{5. 結 言}

本研究では, クラスター計算とバンド計算を併用すること
で, $\mathrm{Fe}_{2} \mathrm{VAl}$ の V サイトに Hf, Ta, W を， Fe サイトに Ir を 部分置換することにより, 電子輸送特性に大きな影響を与え ることなく，格子熱伝導度のみを低減できると予測した。

Hf, Ir が非常に高価な元素であることを考慮し，Vサイトへ の Ta あるいは $\mathrm{W}$ 置換が，実用的な熱電材料の開発に望ま しいと判断した。さらに, 理論計算により得られた知見を 用いて, $\mathrm{Fe}_{2}\left(\mathrm{~V}_{1-x} \mathrm{Ta}_{x}\right) \mathrm{Al}_{0.95} \mathrm{Si}_{0.05}(x=0,0.025,0.05)$, $\mathrm{Fe}_{2}\left(\mathrm{~V}_{0.9-x} \mathrm{Ta}_{x} \mathrm{Ti}_{0.1}\right) \mathrm{Al}(x=0,0.10,0.20), \mathrm{Fe}_{2}\left(\mathrm{~V}_{0.9-2 x} \mathrm{~W}_{x} \mathrm{Ti}_{0.1+x}\right) \mathrm{Al}$ $(x=0,0.05,0.10)$ を作製し, その熱電物性の温度依存性を評 価した. その結果, 電子物性には大きな影響を与えずに, 格 子熱伝導度のみを大きく低減させることに成功した．特に， $\mathrm{Ta}$ で部分置換を行った $n$ 型材料では, 格子熱伝導度の低減 に加え, ゼーベック係数がわずかではあるが増大し, それら の相乗効果により $Z T$ が 5 倍大きくなった. 以上の結果から 我々が提案する, クラスタ一計算を利用した材料設計指針が 極めて有効であると結論する.

文献

1) Y. Nishino, H. Kato and U. Mizutani: Phys. Rev. B 63(2001) 233303-233306.

2) Y. Nishino, S. Deguchi and U. Mizutani: Phys. Rev. B 74(2006) $115115-115120$

3) C. S. Lue, C. F. Chen, J. Y. Lin, Y. T. Yu and Y. K. Kuo: Phys. Rev. B 75(2007) 064204-064209.

4) H. Goto, Y. Terazawa, M. Mikami and T. Takeuchi: Mater. Trans. 51(2010) 2139-2144.

5) T. Takeuchi, N. Nagasako, R. Asahi and U. Mizutani: Phys. Rev. B 74(2006) 054206-054217.

6) P. G. Klemens: Proc. Phys. Soc., London Sect. A 68(1955) $1113-1128$.

7) A. F. loffe and A. R. Regel: Prog. Semicond. 4(1960) 237.

8) H. Adachi, M. Tsukada and C. Satoko: J. Phys. Soc. Jpn. 45 (1978) 875-883.

9) http://www.wien2k.at/

10) K. Schwarz and P. Blaha: Computational Materials Science 28 (2003) 259-273.

11) T. Yamamoto, T. Hamada, T. Yamasaki, M. Okamoto, T. Ohno and T. Uda: Introduction to First Principles Simulation, (AdvanceSoft Corporation, 2004).

12) T. Takeuchi: Mater. Trans. 50(2009) 2359-2365.

13) R. Venkatasubramanian, E. Siivola, T. Colpitts and B. O'Quinn: Nature 413(2001) 597-602.

14) M. V. Simkin and G. D. Mahan: Phys. Rev. Lett. 84(2000) 927930. 